\title{
Dietary intake of patients with ischemic heart disease in Hayatabad medical complex Peshawar
}

Falak Zeb*, Bilal Ali Khan, Muhammad Samiullah, Saleem Khan and Ayesha Syed

Department of Human Nutrition, The University of Agriculture-Peshawar-Pakistan

*Corresponding author's email: falak106@gmail.com

Citation

Falak Zeb, Bilal Ali Khan, Muhammad Samiullah, Saleem Khan and Ayesha Syed. Dietary Intake of patients with ischemic heart disease In Hayatabad medical complex Peshawar. Pure and Applied Biology. Vol. 5, Issue 4, pp950956. http://dx.doi.org/10.19045/bspab.2016.50120

Received: 22/03/2016 Revised: 28/06/2016 Accepted: 20/08/2016 Online First: 28/08/2016

\section{Abstract}

A hospital based case control study was conducted in Hayatabad Medical Complex Peshawar to assess the nutritional and dietary intake of patients with ischemic heart disease. A total of 100 adults were selected (50 control: 50 cases) from out-patient department. The subjects were interviewed and data were collected about physical activity, biochemical parameters, anthropometric measurements and dietary intake through a standard questionnaire. Serum glucose and lipid profile were determined by micro-Lab 300. Statistical analysis was carried out by using SPSS software version 16. The mean waist to hip ratio (WHR), serum glucose, triglycerides (TG), low density lipoprotein (LDL) and high density lipoprotein were significantly $(P<0.05)$ different in both groups, while pulse rate, blood pressure, body mass index (BMI), waist and hip circumferences were changed non-significantly. The mean intake of fiber, calcium, iron, thiamine, vitamin-C and A was significantly $(P<0.05)$ different, while intake of all three macronutrients, phosphorous, zinc, iodine, riboflavin and niacin was non-significantly different in case and control group. The frequent consumption of meat, milk, fruits, vegetables, pulses and nuts was significantly $(P<0.05)$ changed, while that of poultry and cereals non-significantly changed. Hypertension, obesity, sedentary life, diabetes, increased level of TG, LDL and low intake of nutrient dense food may be associated with ischemic heart disease. Dietary and lifestyle changes play a vital role in the progression of heart diseases.

Keywords: Biochemical parameter; Serum glucose; Lipoprotein; Body mass index

\section{Introduction}

Ischemic heart disease (IHD) involves myocardial impairment due to reduced blood flow through the coronary arteries, commonly caused by atherosclerotic narrowing [1]. IHD belongs to groups of cardiovascular diseases [2]. Worldwide, cardiovascular disease (CVD) accounts for
16.7 million deaths annually, with ischemic heart disease alone accounting for $13.3 \%$ of mortality $[2,3]$. IHD will become the main cause of global disease burden in 2020 [4]. IHD prevalence is increasing in low income and middle income countries with about $80 \%$ of the burden [2]. Pakistanis are part of ethnic group that have highest prevalence of 
CVD [5]. A population based cross-sectional survey has shown that 1 in 4 middle aged adults in Pakistan has prevalent IHD. It was estimated that in Pakistan 154, 3383 deaths were due to cardiovascular disease and over $30 \%$ of population was at risk of cardiovascular disease [5]. The risk factors responsible for CVD are mostly established in childhood and adolescence that include tobacco use, dietary behaviors, physical activity, obesity and diverse childhood experiences [6, 7]. Epidemiological evidence suggests that dietary changes are associated with the nutritional transition, specifically the increase consumption of energy dense diets i-e high in unhealthy fats, oils, sodium and sugars have contributed to an increase incidence of CVD in low and middle income countries [8]. Excessive intake of alcohol clearly increases IHD risk and moderate alcohol consumption and physical activity can reduce the risk $[9,10]$. Various studies indicates that each of the five risk factors i.e. high blood pressure, high cholesterol level, diabetes, obesity and current smoking are independently associated with the likelihood of developing IHD and patients with high blood pressure, high cholesterol level and diabetes are 1.4, 1.4 and 1.2 times more likely to develop IHD [11]. Researches on the risk factors of ischemic heart disease are mostly derived from the developed countries while risk factors may vary between populations due to ethnic diversity. Considering all the risk factors, the increasing global trends of ischemic heart disease and the importance of human health, the present study was conducted at the cardiac rehabilitation center of Hayatabad Medical Complex (HMC), Peshawar to determine the dietary intake of patients with the ischemic heart disease. Materials and methods

A hospital based case control study was designed to determine the association of dietary and nutritional intake pattern and anthropometric measurements with ischemic heart disease individuals of age $>20$ years at Cardiac Rehabilitation Center of Hayatabad Medical Complex, Peshawar. Ethical approval was obtained from the Institutional Research and Ethics Board of Postgraduate Medical Institute Peshawar, prior to conducting the study consent was obtained from the subjects for their participation in the study. A total of 100 adults were selected including 50 cases as diagnosed cases of IHD from hospital and 50 control matched for age and with no previous history of cardiac occurrence. Pregnant females and patients suffering from mental diseases were excluded. Patients who had a previous history of treatment for cardiac diseases like percutaneous transluminal coronary angioplasty (PTCA) or bypass graft surgery were also excluded. Sociodemographic information was determined by interviewing the subjects. General examinations for signs of anemia, pulse rate and blood pressure were carried out. All study subjects provided $5 \mathrm{ml}$ fasting blood sample. Serum was obtained by centrifuging blood at $4000 \mathrm{rpm}$ for five minutes. Fresh serum samples were used for the estimation of fasting blood glucose and lipid profile. Lipid profile and glucose level were determined in the blood serum by using DAILAB Company kits, Austria through Micro Lab 300. Anthropometric measurements including weight, height, BMI (Body mass index), waist and hip measurements were recorded by adopting anthropometric assessment procedures, recommended by WHO [12]. The dietary data was collected through face to face interviews using twenty four hour dietary recall and food frequency questionnaire (FFQs). Macro and micronutrients intakes were estimated using relevant food composition table for Pakistan. Data were analyzed by using statistical package for Social Sciences (SPSS Inc., 2007) for 
comparative statistics at $95 \%$ confidence interval. There was a significant $(P<0.05)$ difference between socioeconomic status of case group compared to control group, with $38 \%$ of case and $86 \%$ of control were having satisfactory socioeconomic status, while $62 \%$ of case group and $14 \%$ of control group were having non-satisfactory socioeconomic status. Percentage and frequency of smoking and tobacco use was significantly $(P<0.05)$ different while physical activity level was non-significantly different in both groups (Table 1). The mean WHR, serum glucose, triglycerides, low density lipoprotein and high density lipoprotein were significantly $(P<0.05)$ different in both groups (Table 2$)$. The mean intake of fiber, calcium, iron, thiamine, vitamin-C and A was significantly $(P<0.05)$ different, while intake of macronutrients, phosphorous, zinc, iodine, riboflavin and niacin was non-significantly different in case and control group (Table 3 ). The frequent consumption of meat, milk, fruits, vegetables, pulses and nuts was significantly $(P<0.05)$ changed, while that of poultry and cereals were non-significantly changed (Table 4). Physical activity counted as a main tool to reduce the development of CVD, as reported by Tanasescu et al. (2003) that physical activity was associated with the reduction in risk of CVD, cardiovascular death and total mortality in men with type 2 diabetes [13]. Physical inactive individuals had highest fatal IHD hazard ratios [10]. Our results show agreement up to some extent with Zahidullah et al. (2012) who reported smokers $(43.27 \%)$ and sedentary life style individuals (53.84\%) in a study of 104 ischemic heart disease patients [14]. Unal et al. (2004) reported that decline in ischemic heart disease mortality rate of $58 \%$ population risk factor blood pressure accounted for $9.5 \%$ decrease [15]. Dhaliwal and Wellborn (2009) reported that waist to hip ratio and smoking was identified as main independent risk factors for IHD deaths in Australian individuals in a multivariate analysis. Men have more visceral fat in their body compared to women which may be responsible for cardiac risks [16]. Abbas et al. (2009) reported that in Pakistani population men had higher total cholesterol levels and women had lower LDL cholesterol while women had higher HDL cholesterol than men [17]. The normal HDL cholesterol was not found in both genders. Ghuge et al., (2012) reported that mean serum triglyceride levels were significantly higher in IHD patients than in controls. They also found that mean HDL concentration was low in IHD patients and higher in control group [18]. Our findings were in consensus with Kusuma and Urooj (2002), for the mean intake of protein, carbohydrate, calcium, iron, thiamine and riboflavin. On other side our study findings are in agreement with Kusuma and Urooj (2002), who reported that the mean intake of all food items, except cereals, was lower when compared to the desirable dietary pattern (DDP) [19]. Frank et al. (2000) found that the occurrence of CHD decreased after consuming useful nutrients like cereal fiber and folate. This indicates that different dietary patterns in different parts of the world have different effects on the populations consuming those diets and dietary diversity can affect the health of individuals [20]. 
Table 1. Socioeconomic and demographic status of case and control group $(n=100)$

\begin{tabular}{|c|c|c|c|c|}
\hline \multicolumn{2}{|l|}{ Variable } & Case (50) & Control (50) & P-value \\
\hline \multicolumn{2}{|l|}{ Age (years) } & $55.4 \pm 11.6$ & $26.2 \pm 8.78$ & $0.005^{*}$ \\
\hline \multirow{2}{*}{ Gender } & Male & $29(58)$ & $30(60)$ & \multirow[t]{2}{*}{0.5} \\
\hline & Female & $21(42)$ & $20(40)$ & \\
\hline \multirow[t]{2}{*}{ Marital status } & Married & $48(98)$ & $12(24)$ & \multirow[t]{2}{*}{$0.000^{*}$} \\
\hline & unmarried & $1(2)$ & $38(76)$ & \\
\hline \multirow[t]{2}{*}{ Family type } & Joint & $37(74)$ & $17(34)$ & \multirow{2}{*}{$0.000^{*}$} \\
\hline & Nuclear & $13(46)$ & $33(66)$ & \\
\hline \multirow[t]{2}{*}{ Family size } & $<5$ & $5(10.2)$ & $10(20)$ & \multirow[t]{2}{*}{0.174} \\
\hline & $\geq 5$ & $44(89.8)$ & $40(80)$ & \\
\hline \multirow[t]{2}{*}{ Accommodation } & Own & $34(68)$ & $41(82)$ & \multirow[t]{2}{*}{0.106} \\
\hline & Rented & $16(32)$ & $9(18)$ & \\
\hline \multirow[t]{2}{*}{ House condition } & cemented & $31(62)$ & $47(94)$ & \multirow[t]{2}{*}{$0.000 *$} \\
\hline & Muddy & $19(38)$ & $3(6)$ & \\
\hline \multirow[t]{4}{*}{ Occupation } & government & $4(8)$ & $3(6)$ & \multirow[t]{4}{*}{0.561} \\
\hline & Private & $15(30)$ & $12(24)$ & \\
\hline & Retired & $3(6)$ & $1(2)$ & \\
\hline & Jobless & $28(56)$ & $34(68)$ & \\
\hline \multirow[t]{4}{*}{ Education } & Illiterate & $39(79.6)$ & $4(8)$ & \multirow[t]{4}{*}{$0.000 *$} \\
\hline & Primary & $4(8.2)$ & $0(0)$ & \\
\hline & secondary & $5(10.2)$ & $23(46)$ & \\
\hline & graduate above & $1(2)$ & $23(46)$ & \\
\hline Monthly income & & $23600 \pm 20555.2$ & $45900 \pm 27405$ & $0.001 *$ \\
\hline \multirow{2}{*}{$\begin{array}{l}\text { Socioeconomic } \\
\text { status }\end{array}$} & satisfactory & $19(38)$ & $43(86)$ & \multirow[t]{2}{*}{$0.000^{*}$} \\
\hline & non-satisfactory & $31(62)$ & $7(14)$ & \\
\hline \multirow[t]{3}{*}{ Smoking History } & current smoker & $0(0)$ & $10(20)$ & \multirow[t]{3}{*}{$0.000 *$} \\
\hline & former smoker & $15(30)$ & $1(2)$ & \\
\hline & non smoker & $15(70)$ & $39(78)$ & \\
\hline \multirow[t]{2}{*}{ Tobacco Use } & No & $42(84)$ & $50(100)$ & \multirow[t]{2}{*}{$0.003 *$} \\
\hline & Yes & $8(16)$ & $0(0)$ & \\
\hline \multirow{4}{*}{$\begin{array}{l}\text { Physical Activity } \\
\text { Level }\end{array}$} & Survival & $36(72)$ & $18(36)$ & \multirow[t]{4}{*}{0.415} \\
\hline & Light & $6(12)$ & $16(32)$ & \\
\hline & Moderate & $7(14)$ & $15(30)$ & \\
\hline & Heavy & $1(2)$ & $1(2)$ & \\
\hline
\end{tabular}


Table 2. Anthropometric and Biochemical measurements of cases and controls $(\mathbf{n}=100)$

\begin{tabular}{|l|l|l|l|}
\hline \multirow{2}{*}{ Variables } & \multicolumn{2}{|c|}{ Mean \pm SD } & \multirow{2}{*}{ P-value } \\
\cline { 2 - 4 } & Control group (50) & Case group (50) & \\
\hline Weight & $66.4 \pm 14.5$ & $66.2 \pm 12.9$ & 0.945 \\
\hline Height & $165.64 \pm 8.6$ & $164.3 \pm 11.7$ & 0.515 \\
\hline BMI & $24.0 \pm 4.3$ & $24.2 \pm 4.9$ & 0.887 \\
\hline Hip circumference & $36.5 \pm 5.0$ & $36.6 \pm 5.6$ & 0.903 \\
\hline Waist circumference & $33.6 \pm 4.9$ & $35.5 \pm 7.7$ & 0.156 \\
\hline WHR & $0.9 \pm 0.1$ & $1.0 \pm 0.1$ & $0.001^{*}$ \\
\hline Pulse rate & $76.3 \pm 6.7$ & $76.2 \pm 10.0$ & 0.991 \\
\hline Systolic & $119.3 \pm 4.9$ & $122.0 \pm 21.8$ & 0.401 \\
\hline Diastolic & $79.3 \pm 3.6$ & $79.6 \pm 11.8$ & 0.846 \\
\hline Plasma glucose & $140.5 \pm 83.2$ & $112.8 \pm 22.7$ & $0.000^{*}$ \\
\hline Blood cholesterol & $191.6 \pm 45.5$ & $176.4 \pm 34.82$ & 0.157 \\
\hline Triglycerides & $187.3 \pm 48.7$ & $148.5 \pm 35.3$ & $0.038^{*}$ \\
\hline LDL & $105.2 \pm 40.8$ & $114.3 \pm 24.6$ & $0.023^{*}$ \\
\hline HDL & $49 \pm 10.08$ & $58.1 \pm 6.1$ & $0.007^{*}$ \\
\hline
\end{tabular}

BMI= Body Mass Index; WHR= Waist to hip ratio; LDL= Low Density Lipoprotein; HDL= High Density Lipoprotein

Table 3. Nutrient intake of case and control group $(n=100)$

\begin{tabular}{|l|l|l|l|}
\hline \multirow{2}{*}{ Variables } & Mean \pm SD & Case (50) & \multirow{2}{*}{ P-value } \\
\cline { 2 - 4 } & Control (50) & $2183.6 \pm 545.12$ & 0.688 \\
\hline Energy & $2017.7 \pm 565.8$ & $57.2 \pm 17.34$ & 0.207 \\
\hline Protein & $54.1 \pm 14.5$ & $95.8 \pm 17.8$ & 0.347 \\
\hline Fats & $86.2 \pm 18.4$ & $276 \pm 93.42$ & 0.266 \\
\hline Farbohydrates & $268 \pm 81.2$ & $12.6 \pm 3.14$ & $0.036^{*}$ \\
\hline Calcium & $11.06 \pm 1.42$ & $691 \pm 191.4$ & $0.000^{*}$ \\
\hline Phosphorus & $523 \pm 101.5$ & $1110 \pm 442.7$ & 0.061 \\
\hline Iron & $1030 \pm 368.3$ & $26.7 \pm 9.23$ & $0.005^{*}$ \\
\hline Zinc & $23.8 \pm 4.1$ & $9.9 \pm 3.3$ & 0.12 \\
\hline Iodine & $9.9 \pm 2.6$ & $43.2 \pm 21.2$ & 0.118 \\
\hline Thiamine & $31.2 \pm 12.3$ & $1.1 \pm 0.5$ & $0.04^{*}$ \\
\hline Riboflavin & $1.06 \pm .42$ & $1.1 \pm .42$ & 0.26 \\
\hline Niacin & $0.88 \pm .32$ & $7.3 \pm 3.4$ & 0.102 \\
\hline Vitamin-C & $5.7 \pm 2.1$ & $53.8 \pm 29.8$ & $0.000^{*}$ \\
\hline Beta-carotene & $29.08 \pm 8.9$ & $3460 \pm 2340.1$ & $0.000^{*}$ \\
\hline Vitamin-A & $1800 \pm 563.7$ & $21100 \pm 16611.7$ & $0.000^{*}$ \\
\hline
\end{tabular}


Table 4. Food Frequency of case and control group $(n=100)$

\begin{tabular}{|c|c|c|c|c|}
\hline \multirow{2}{*}{\multicolumn{2}{|c|}{ Variable }} & \multicolumn{2}{|c|}{ Frequency (\%) } & \multirow{3}{*}{\begin{tabular}{|l|} 
P-value \\
$0.001^{*}$ \\
\end{tabular}} \\
\hline & & \multirow{2}{*}{\begin{tabular}{|l|} 
Case (50) \\
$40(80)$ \\
\end{tabular}} & \multirow{2}{*}{$\begin{array}{l}\text { Control (50) } \\
23(40)\end{array}$} & \\
\hline \multirow[t]{3}{*}{ Meat group } & Never & & & \\
\hline & 1 to 3 & $3(6)$ & $16(32)$ & \\
\hline & 4 to 6 & $7(14)$ & $11(22)$ & \\
\hline \multirow[t]{3}{*}{ Poultry } & Never & $22(44)$ & $12(24)$ & \multirow[t]{3}{*}{0.074} \\
\hline & 1 to 3 & $26(52)$ & $37(74)$ & \\
\hline & 4 to 6 & $2(4)$ & $1(2)$ & \\
\hline \multirow[t]{3}{*}{ Milk and milk products } & Never & $17(34)$ & $0(0)$ & \multirow[t]{3}{*}{$0.000 *$} \\
\hline & 1 to 3 & $31(62)$ & $47(94)$ & \\
\hline & 4 to 6 & $2(4)$ & $3(6)$ & \\
\hline \multirow[t]{3}{*}{ Fruits } & Never & $6(12)$ & $0(0)$ & \multirow[t]{3}{*}{$0.002 *$} \\
\hline & 1 to 3 & $12(24)$ & $16(32)$ & \\
\hline & 4 to 6 & $8(16)$ & $21(42)$ & \\
\hline \multirow[t]{2}{*}{ Vegetable group } & Never & $20(40)$ & $1(2)$ & \multirow[t]{2}{*}{$0.000^{*}$} \\
\hline & 1 to 3 & $30(60)$ & $49(98)$ & \\
\hline \multirow[t]{3}{*}{ Pulses } & Never & $9(18)$ & $0(0)$ & \multirow[t]{3}{*}{$0.001 *$} \\
\hline & 1 to 3 & $37(74)$ & $50(100)$ & \\
\hline & 4 to 6 & $4(8)$ & $0(0)$ & \\
\hline \multirow[t]{2}{*}{ Cereals } & Never & $1(2)$ & $0(0)$ & \multirow[t]{2}{*}{0.315} \\
\hline & 1 to 3 & $49(98)$ & $50(100)$ & \\
\hline \multirow{3}{*}{ Confectionaries } & Never & $29(58)$ & $2(4)$ & \multirow[t]{3}{*}{$0.000^{*}$} \\
\hline & 1 to 3 & $20(40)$ & $45(90)$ & \\
\hline & 4 to 6 & $1(2)$ & $3(6)$ & \\
\hline \multirow[t]{2}{*}{ Beverages } & Never & $4(8)$ & $0(0)$ & \multirow[t]{2}{*}{$0.041^{*}$} \\
\hline & 1 to 3 & $46(92)$ & $50(100)$ & \\
\hline \multirow[t]{3}{*}{ Fast foods } & Never & $49(98)$ & $11(22)$ & \multirow[t]{3}{*}{$0.000^{*}$} \\
\hline & 1 to 3 & $1(2)$ & $38(76)$ & \\
\hline & 4 to 6 & $0(0)$ & $1(2)$ & \\
\hline \multirow[t]{3}{*}{ Nuts } & Never & $34(68)$ & $5(10)$ & \multirow[t]{3}{*}{$0.000^{*}$} \\
\hline & 1 to 3 & $13(26)$ & $23(46)$ & \\
\hline & 4 to 6 & $3(6)$ & $22(44)$ & \\
\hline
\end{tabular}

\section{Conclusion and recommendations}

There was no significant difference in the mean energy, protein, carbohydrates and fat intake of the groups. Consumption of meat, poultry, milk and milk products, fruits, vegetables, pulses, and nuts was significantly higher $(P<0.05)$ in control group as compared to case group.

Patients should consume balanced diet by eating variety of foods including fruits, vegetables, poultry and fish etc. They should concert nutritionist or dietitian for nutritional counseling.

Authors' contributions

Research designing, data collection and paper writing; F Zeb, Computation and data analysis; M Samiullah, Data analysis; S Khan, Data collection, biochemical and anthropometric assessment; A Syed, Research designing, data collection, data entry, and paper writing; BA Khan. 


\section{Acknowledgment}

The authors are very much indebted to all clients for participation in the study.

\section{References}

1. Warrell D, Cox T, Firth J \& Benz E (2004). 'Oxford Textbook of Medicine; 4th Edition' Oxford University Press, Oxford.

2. World Health Organization (WHO). (2009e). World health statistics. Geneva: World Health Organization.

3. Jaffar TH, Jafary FH, Jessani S \& Chaturvedi $N$ (2004). Heart disease epidemic in Pakistan: Women and men at equal risk. Am. Hear. J 150: 221-226.

4. Murray CJ \& Lopez AD (1996). Alternative projections of mortality and disability by cause 1990-2020. Global burden of disease study. Lancet 349: 1498-1504.

5. World Health Organization (WHO). (2002). Cardiovascular disease: prevention and control.

6. Celermajer DS \& Ayer JG (2006). Childhood risk factors for adult cardiovascular disease and primary prevention in childhood. Heart 92(11): 1701-1706.

7. Dong M, Giles WH, Felitti VJ, Dube S R, Williams JE, Chapman DP \& Anda RF (2004). Insights into causal pathways for ischemic heart disease: Adverse childhood experiences study. Circulation 110(13): 1761- 1766.

8. Hu FB (2008). Globalization of food patterns and cardiovascular disease risk. Circulation 118(19), 1913-1914.

9. Lucas DL, Brown RA, Wassef M \& Giles TD (2005). Alcohol and the cardiovascular system research challenges and opportunities. J. Am. Coll. Cardiol 45(12): 1916-1924.

10. Pedersen JO, Heitmann BL, Schnohr P \& Gronbaek M (2007). The combined influence of leisure-time physical activity and weekly alcohol intake on fatal ischaemic heart disease and all-cause mortality. Euro. Heart. J 29: 204-212.

11. Yusuf HR, Giles WH, Croft JB, Anda RF \& Casper ML (1998). Impact of multiple risk factor profiles on determining cardiovascular disease risk. Preven. Med 27: 1-9.

12. World Health Organization (WHO). (1995). Physical status: the use and interpretation of anthropometry. Geneva: WHO 1995: Technical Report Series no. 854.

13. Tanasescu M, Leitzmann MF, Rimm EB \& Hu FB (2003). Physical activity in relation to cardiovascular disease and total mortality among men with type-2 diabetes. Circulation 107: 2435-9.

14. Zahidullah M, Aasim M, Khan I, Muhammadzai HZ, Shah MA, Ali N, Mohammad A, Muzahir A \& Rehman M (2012). Evaluation of patients with coronary artery disease for major modifiable risk factors for ischemic heart disease. J. Ayub. Med. Coll. Abbottabad 24(2): 102-105.

15. Unal B, Critchley JA \& Capewell S (2004). Explaining the decline in coronary heart disease mortality in England and wales between 1981 and 2000. Circulation 109: 1101-1107.

16. Dhaliwal SS \& Welborn TA (2009). Central obesity and cigarette smoking are key determinants of cardiovascular disease deaths in Australia. A public health perspective. Prevent. Med 49, 153-157.

17. Abbas S \& Kitchlew AR (2009). Disease Burden of Ischemic Heart. American Med. Assoc 282(22): 2149-2155.

18. Ghuge GD, Zine R \& Mogrekar M (2012). Lipid profile of patients with ischemic heart disease from rural area of marthawada region, India. Ijbar 3(10): 767-769.

19. Kusuma K \& Urooj A (2002). Nutritional status and plasma lipid profile in selected Ischemic Heart Disease (IHD) patients. $J$. Hum. Ecol 13(6): 449-454.

20. Frank BH, Eric BR, Meir JS, Alberto AS, Donna S \& Walter CW (2000). Prospective study of major dietary patterns and risk of coronary heart disease in men. Amr. J. clin. Nutr 72: 912-921. 